\title{
Long-term effects of burning Festuca and Stipa-Agropyron grasslands
}

\author{
B. PYLYPEC AND J.T. ROMO
}

Authors are with the Department of Plant Sciences, 51 Campus Drive, University of Saskatchewan, Saskatoon, Sask. S7N 5A8.

\begin{abstract}
The effects of early spring burning on current year standing crop, litter, and total standing crop (current year standing crop plus litter) were examined in Festuca- and Stipa-Agropyron-dominated communities in central Saskatchewan over an 11-year period in a paired design with burned sites compared to adjacent control sites that were not burned. In Festuca communities current year standing crop was reduced in the first and third years $(\mathbf{P}=\mathbf{0 . 0 1 0})$ after burning. Burning Stipa-Agropyron-communities tended to reduce current year standing crop, but the differences were not significant $(P<0.050)$ compared to control. Increasing precipitation stimulated current year standing crop after burning Festuca $\left(\mathrm{P}<0.001, \mathrm{r}^{2}=0.33\right)$ and Stipa-Agropyron $(\mathrm{P}<0.001$, $\left.\mathbf{r}^{2}=0.55\right)$ communities. Litter and current year standing crop were correlated $\left(R^{2}=0.24, P=0.002\right)$ for Festuca indicating beneficial and detrimental effects of litter on production at low and high amounts, respectively. Litter and current year standing crop were not correlated $(P=0.964)$ for Stipa-Agropyron. In both communities total standing crop increased until about the eighth year after burning while the mass of litter appeared to reach a plateau around 11 years.
\end{abstract}

Key Words: Agropyron dasystachyum, Fescue Prairie, Festuca hallii, fire, litter, Northern Mixed Prairie, primary productivity, Stipa curtiseta, total standing crop

Prescribed burning is useful for achieving many conservation goals in grasslands. Beneficial effects of burning on production have been demonstrated in mesic grasslands such as Tallgrass Prairie where C4 grasses dominate (Wright and Bailey 1982, Collins and Wallace 1990). By contrast in the Northern Mixed Prairie and in Fescue Prairie dominated by C3 grasses, primary production is often reduced after burning (Redmann et al. 1993). For example, peak green biomass in Fescue Prairie recovered 2 to 3 years after burning, while in Mixed Prairie dominated by western porcupine grass (Stipa curtiseta Hitchc.) and northern wheatgrass (Agropyron dasystachyum [Hook.] Scribn.), recovery was delayed 4 to 5 years. Total graminoid biomass (green plus standing dead) in areas previously burned was comparable to unburned sites 3 to 4 years after burning, but recovery of litter took much longer in the Northern Mixed Prairie of western North Dakota (Dix 1960).

Litter alters the microenvironment of grasslands and affects productivity (Willms 1988, Facelli and Pickett 1991). Whereas excessive litter reduces productivity in Tallgrass Prairie (Vogl 1974, Boerner 1982), litter has positive effects on herbage production apparently by reducing evaporation and making more

Manuscript accepted 11 Mar. 03.

\section{Resumen}

Se examinaron los efectos de la quema a inicios de primavera sobre la cosecha en pie actual, mantillo y cosecha en pie total (cosecha en pie del año actual + mantillo) de comunidades de Festuca y comunidades dominadas por Stipa-Agropyron situadas en la región central de Saskatchewan. El estudio se llevo a cabo en un período de 11 años en un diseño apareado con sitios quemados adyacentes a sitios control que no fueron quemados. En las comunidades de Festuca la cosecha en pie actual se redujo en el primer y tercer años $(P=0.010)$ después de la quema. La quema de comunidades de Stipa-Agropyron tendió a reducir la cosecha en pie del año actual, pero las diferencias no fueron significativas $(P<0.050)$ en comparación con el control. El aumento en la precipitación estimuló la cosecha en pie del presente año después de la quema en las comunidades de Festuca $(P<0.001$, $\left.\mathbf{r}^{2}=0.33\right)$ y Stipa-Agropyron $\left(P<0.001, r^{2}=0.55\right)$. El mantillo y la cosecha en pie actual estuvieron correlacionadas $\left(R^{2}=0.24, P=\right.$ 0.002) en la comunidad de Festuca, indicando efectos benéficos $y$ detrimentales del mantillo en la producción en cantidades bajas y altas respectivamente. El mantillo y la cosecha en pie actual no estuvieron correlacionadas $(P=0.964)$ en la comunidad de StipaAgropyron. En ambas comunidades la cosecha en pie total se incremento hasta aproximadamente el octavo año después de la quema mientras que la masa de mantillo pareció alcanzar su máximo nivel alrededor de los 11 años.

water available for plant growth especially in xeric Northern Mixed Prairie (Willms et al. 1986, 1993). Herbage production increased slightly with litter removal in Fescue Prairie but reductions in production occurred in Mixed Prairie (Willms et al. 1986). Climatic effects, particularly the amount of precipitation, also strongly influence primary productivity of Northern Mixed Prairie (Smoliak 1986) and Fescue Prairie (Bork et al. 2001).

Understanding the dynamics of standing crop of plants after burning is relevant to developing strategies for conserving Festuca- and Stipa-Agropyron-dominated grasslands. The purpose of this study was to examine the effects of burning over an 11-year period on current year standing crop, and the recovery over time of litter and total standing crop in Fescue Prairie and Northern Mixed Prairie dominated by western porcupine grass and northern wheatgrass.

\section{Study site}

This study was conducted at the University of Saskatchewan, Kernen Prairie located $1 \mathrm{~km}$ east of Saskatoon, Saskatchewan $\left(52^{\circ} 10^{\prime} \mathrm{N}, 106^{\circ} 33^{\prime} \mathrm{W}\right.$; elevation $\left.510 \mathrm{~m}\right)$. This 130 -ha remnant 
grassland has been relatively undisturbed since the 1930s except for periodic mowing on portions of it until 1976 (Pylypec 1986). Since 1986 various parts of the prairie have been burned by prescribed fires, and the impacts of these fires on the vegetation have been described in Redmann et al. (1993), Romo et al. (1993), Grilz and Romo (1994, 1995), Archibold et al. (1998) and Ripley and Archibold (1999).

Kernen Prairie lays in an ecotone between the Northern Mixed Prairie and the Boreal Forest. Therefore, the Festucadominated plant communities at Kernen Prairie are near the southern extent of their distribution while the Stipa-Agropyron communities are northerly extensions of typically more southern grasslands. Plains rough fescue (Festuca hallii [Vasey] Piper) dominates the more mesic sites with clayey glaciolacustrine soils within Kernen Prairie whereas western porcupine grass and northern wheatgrass dominate the more xeric sites at slightly elevated topographic positions with sandy loam soils (Baines 1973). A complete floristic inventory of Kernen Prairie is given in Pylypec (1986). Climate in this area has been described by Walter and Lieth (1960-1967) as Type VIII (VII), Boreal (Arid, with cold season). The mean annual temperature is $2.0^{\circ} \mathrm{C}$, ranging from a January mean minimum of $-22.9^{\circ} \mathrm{C}$ to an average maximum of $25.4^{\circ} \mathrm{C}$ in July (Environment Canada 1993). Normal annual precipitation is $347 \mathrm{~mm}$ of which $185 \mathrm{~mm}$ falls during the growing season (April-July).

\section{Methods}

A different portion of Kernen Prairie ranging from 4 to 16 ha was burned in the first 2 weeks of April each year from 1991 to 1997 . At the time of burning prairie crocus (Anemone patens [Bess.] Koch) was in early stages of blooming. Burn areas included representative plant communities of Fescue Prairie (Coupland and Brayshaw 1953) and also of Northern Mixed Prairie (Coupland 1950), and were adjacent to similar controls where no fire has been recorded for the past eight decades.

Except for 2000, aboveground plant biomass at each burn site and the adjacent control area was sampled each year from 1991 to 2001 in late July to mid-August after green biomass had peaked. Previous studies in grasslands of this region have shown that peak standing crop is reached in late July to early August (Redmann et al. 1993, Zhang and Romo 1994, Kowalenko and Romo 1998). Four, 50- by $50-\mathrm{cm}$ quadrats were randomly located along a $20 \mathrm{~m}$ transect in Festuca- and Stipa-Agropyron-dominated communities in each burn area and were compared to 4 quadrats of the same size in unburned control sites located within $20 \mathrm{~m}$ of the burns. In each quadrat, biomass was clipped at ground level and sorted into graminoids, forbs and shrubs. Fallen litter was collected from the surface by hand. All samples were oven-dried at $80^{\circ} \mathrm{C}$ for 24 hours and weighed. A subsample of the graminoids that comprised the bulk of the samples was then separated into green biomass, current year dead biomass and dead biomass from previous years; these subsamples were weighed and their proportions were applied to the entire sample. Graminoids comprised about $95 \%$ of the samples in Festuca-dominated communities and about $99 \%$ in Stipa-Agropyrondominated communities. Current year standing crop was represented by the total of green biomass and current year dead biomass (Redmann 1992). Litter was determined as the sum of fallen, detached, and standing dead biomass from previous years. Total standing crop was the total of litter and current year standing crop.

Means of current year standing crop in control and burned plots were compared with 2-sample t-tests (Snedecor and Cochran 1980) within years after burning $(\mathrm{P} \leq 0.050)$. Regression analysis (Neter et al. 1990) was used to evaluate the relationships between: annual precipitation (August through July), growing season precipitation (April through July) and current year standing crop; litter and current year standing crop, and; the number of years since burning versus litter and total standing crop. Lack-of-fit tests $(P<0.050)$ (Snedecor and Cochran 1980) were used to select the best-fit regression equations.

\section{Results and Discussion}

\section{Precipitation}

Annual precipitation during the 11 years of study ranged from $18 \%$ less to $38 \%$ more than the normal of $347 \mathrm{~mm}$. Precipitation was at least $10 \%$ greater than normal in 4 years, $90 \%$ or less than normal in 5 years, and within $10 \%$ of normal in 2 years. Thus, by repeating this study through time, responses of Festuca- and Stipa-Agropyron-dominated communities to burning were evaluated over wide-ranging amounts of precipitation in many combinations among years. Responses of cur- rent year standing crop, litter and total standing crop after burning discussed here are therefore applicable to a wide range of precipitation conditions.

\section{Current year standing crop}

Annual precipitation and current year standing crop were positively correlated ( $\mathrm{P}$ $<0.001$ ) after burning the Festuca and Stipa-Agropyron communities (Fig. 1). Correlations between current year standing crop and growing season precipitation were significant but lower than the correlation between annual precipitation and current year standing crop for Festuca (Y $\left.=82.5+0.40 \mathrm{X}, \mathrm{r}^{2}=0.21, \mathrm{P}<0.001\right)$ and Stipa-Agropyron $\left(\mathrm{Y}=20.2+0.53 \mathrm{X}, \mathrm{r}^{2}=\right.$ $0.50, \mathrm{P}<0.001)$. Increasing current year standing crop with precipitation was expected because precipitation constrains production in North American grasslands (Sims and Singh 1978). Herbage production also increases with precipitation in Stipa-Bouteloua-dominated grasslands (Smoliak 1986), grazed Fescue Prairie (Bork et al. 2001) and Tallgrass Prairie (Briggs and Knapp 1995). The variation in current year standing crop within precipitation amounts is attributed to harvesting being done in areas burnt in different years and they were therefore in different chronological stages of recovery after burning. Differences in production potential among burned areas likely also contributed to the variation in current year standing crop.

Burning mesic grasslands often stimulates production where conditions are often light- or nutrient-limited (Old 1969, Knapp 1984, Town and Owensby 1984 , Abrams et al. 1986). However, current year standing crop in Festuca communities was reduced $(\mathrm{P}<0.050)$ in the first and third years after burning (Table 1). A trend of less current year standing crop was observed after burning, but there was no difference $(\mathrm{P}<0.050)$ compared to the control in the second year and after the third year. The longevity of reduced current year standing crop in the Festuca communities is close to a 2 to 3 year reduction reported by Redmann et al. (1993). On the other hand, current year production of plains rough fescue was not affected by burning in early April in Alberta (Gerling et al. 1995).

Despite a trend of less current year standing crop after burning, differences were not significant $(\mathrm{P}<0.050)$ between control and burned Stipa-Agropyron communities within all years (Table 1). That burning had no effect on current year standing crop in Stipa-Agropyron-domi- 

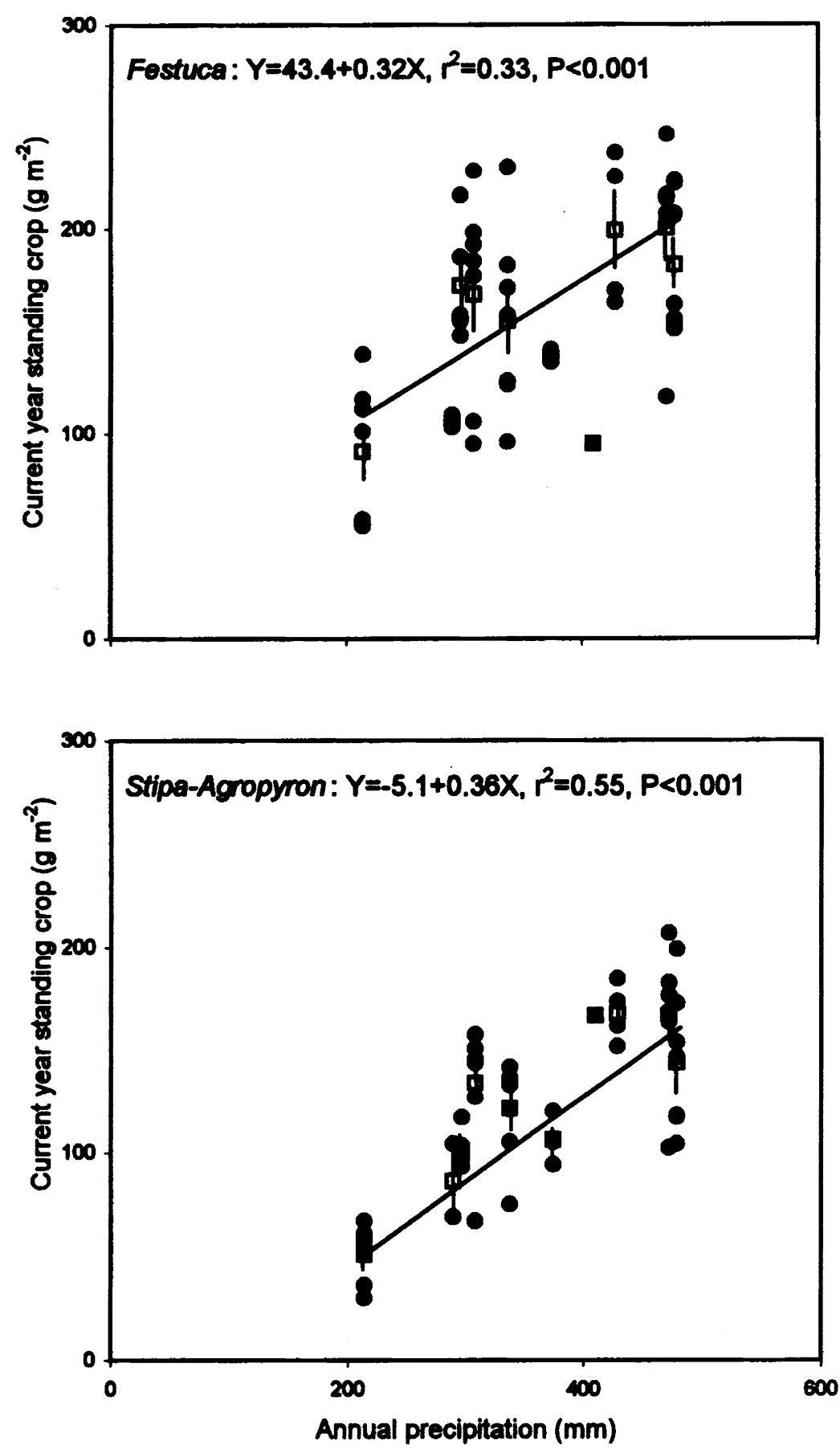

Fig. 1. Fitted regression lines and observed values for current year standing crop versus annual precipitation (August through July) in Festuca- and Stipa-Agropyron-dominated plant communities. Solid circles are observed current year standing crop and open squares with vertical lines are means $\pm \mathrm{SE}$ for the control. Solid squares represent overlapping values for current year standing crop in control and after burning.

nated grasslands is at odds with earlier studies where productivity was reduced by burning (Redmann 1978, Engle and Bultsma 1984, Whisenant and Uresk 1989). Burning during a drought reduced current year standing crop of StipaAgropyron-dominated grasslands for 4 to 5 years (Redmann et al. 1993). Since the noted in Tallgrass Prairie (Briggs and Knapp 1995). Inherent differences among burned areas undoubtedly also contributed to variability in production within years after burning.

Current year standing crop after burning Festuca communities was correlated with the amount of litter $(\mathrm{Y}=83.5+0.71 \mathrm{X}$ $0.0013 X^{2}, R^{2}=0.24, P=0.002$ ) (Fig. 2), but they were not correlated $(\mathrm{P}=0.964)$ for Stipa-Agropyron. Deviation among observed current year standing crop is attributed to sampling being done during different years after burning and thus different growing conditions. The regression line in Fig. 2 suggests that low amounts of litter benefit production, large amounts are a detriment to production, and production is greatest at intermediate amounts. Willms et al. (1986) also noted increased total standing crop in Fescue Prairie after litter removal, and litter inhibits production in Tallgrass Prairie (Knapp and Seastedt 1986).

Altering the litter layer by burning may indirectly impact current year standing crop of Festuca communities by changing the microenvironment. Litter insulates the soil against incident solar radiation (Rauzi 1960, Willms et al. 1986, 1993) thereby reducing evaporation (Weaver and Rowland 1952, Hopkins 1954) and increasing soil water. Litter also insulates the soil, creating cooler temperatures in summer and warmer temperatures in winter (Johnston et al. 1971). Burning removes litter which in turn causes cascading effects of reduced soil water, increased plant water stress, and reduced production in Fescue Prairie (Redmann 1978, Redmann et al. 1993, Romo et al. 1993, Grilz and Romo 1994). We concur with Willms et al. (1986) that large amounts of litter appear to inhibit production and outweigh benefits of more soil water in Festuca communities. Even though our findings suggest that litter influences production in Festuca communities, additional studies are needed to elucidate relationships.

Production in drier parts of the Northern Mixed Prairie is associated with amounts of litter; production is maximized with maximum amounts of litter (Willms et al. 1986, 1993). Dix (1960) also concluded that litter does not inhibit production in Northern Mixed Prairie. In the present study, evidence suggests no improvement or reduction of current year standing crop in Stipa-Agropyron communities due to litter. The independence of current year standing crop and litter in StipaAgropyron indicates other factors, such as 
Table 1. Current year standing crop in control and burned Festuca- and Stipa-Agropyron-dominated grasslands over the 11 years of study.

\begin{tabular}{|c|c|c|c|c|c|c|c|c|c|c|c|}
\hline \multirow{3}{*}{$\begin{array}{l}\text { Growing seasons } \\
\text { after burning }\end{array}$} & \multicolumn{4}{|c|}{ Festuca } & \multirow[b]{3}{*}{$\mathbf{P}$} & \multicolumn{6}{|c|}{ Stipa-Agropyron } \\
\hline & \multicolumn{2}{|c|}{ Control } & \multicolumn{2}{|c|}{ Burned } & & \multicolumn{2}{|c|}{ Control } & \multicolumn{2}{|c|}{ Burned } & \multirow[b]{2}{*}{$\mathrm{P}$} & \multirow[b]{2}{*}{$\mathrm{n}$} \\
\hline & Mean & SE & Mean & SE & & Mean & SE & Mean & SE & & \\
\hline & \multicolumn{2}{|c|}{$-\left(\mathrm{g} \mathrm{m}^{-2}\right)$} & \multicolumn{2}{|c|}{$\left(\mathrm{g} \mathrm{m}^{-2}\right)-$} & & \multicolumn{2}{|c|}{$\left(\mathrm{g} \mathrm{m}^{-2}\right)$} & \multicolumn{2}{|c|}{$-\left(\mathrm{g} \mathrm{m}^{-2}\right)$} & & \\
\hline 1 & $197 a^{1}$ & 19.3 & $126 \mathrm{~b}$ & 10.5 & 0.01 & $144 a^{1}$ & 6.5 & $114 \mathrm{a}$ & 12.8 & 0.07 & 7 \\
\hline 2 & $208 \mathrm{a}$ & 23.8 & $152 \mathrm{a}$ & 19.8 & 0.10 & $150 \mathrm{a}$ & 14.5 & $116 a$ & 15.0 & 0.13 & 7 \\
\hline 3 & $233 a$ & 13.7 & $167 b$ & 16.2 & 0.01 & $158 \mathrm{a}$ & 15.8 & $131 \mathrm{a}$ & 13.6 & 0.22 & 7 \\
\hline 4 & $230 a$ & 12.3 & $192 a$ & 15.4 & 0.09 & $159 a$ & 13.0 & $142 a$ & 12.2 & 0.34 & 6 \\
\hline 5 & $198 \mathrm{a}$ & 24.6 & $190 \mathrm{a}$ & 27.2 & 0.83 & $134 \mathrm{a}$ & 16.1 & $121 \mathrm{a}$ & 21.5 & 0.64 & 6 \\
\hline 6 & $202 a$ & 31.7 & $163 a$ & 28.2 & 0.39 & $156 a$ & 28.1 & $142 a$ & 25.4 & 0.73 & 5 \\
\hline 7 & $204 a$ & 13.5 & $171 \mathrm{a}$ & 25.4 & 0.31 & $135 \mathrm{a}$ & 20.6 & $131 \mathrm{a}$ & 22.5 & 0.88 & 4 \\
\hline 8 & $187 \mathrm{a}$ & 29.8 & $131 \mathrm{a}$ & 10.2 & 0.22 & $124 a$ & 37.7 & $131 \mathrm{a}$ & 39.9 & 0.90 & 3 \\
\hline 9 & $169 a$ & 46.5 & $146 a$ & 7.0 & 0.72 & $112 \mathrm{a}$ & 66.0 & $86 a$ & 32.0 & 0.78 & 2 \\
\hline 10 & 67 & ----- & 112 & ----- & ---.. & 103 & -... & 58 & -.-- & ----- & 1 \\
\hline 11 & 175 & ----- & 55 & -.--- & ----- & 70 & ----- & 36 & ---.- & ----- & 1 \\
\hline
\end{tabular}

${ }^{1}$ Means followed by similar letters in the same row and plant community are not significantly different $(\mathrm{P}<0.050)$ between the control and burned plots.

precipitation, place greater controls on production than does litter.

\section{Litter}

Litter averaged $391 \mathrm{~g} \mathrm{~m}^{-2}(\mathrm{SE} \pm 12.4)$ in the Festuca control and $254 \mathrm{~g} \mathrm{~m}^{-2}(\mathrm{SE} \pm$ 8.6) in the control for Stipa-Agropyron. During the 11-year period litter increased in both Festuca- and Stipa Agropyrondominated communities, with 79 and $78 \%$ of the variation in litter accounted for by years since burning (Fig. 3). Unexplained variation among observed values probably includes differences in production, transfer to litter, and decomposition among burn areas because observed amounts of litter are grouped by growing seasons after burning. In both Festuca- and StipaAgropyron-dominated communities, litter was reaching a plateau at the end of our study indicating about 11 years are required for the mass of litter to reach levels comparable to unburned sites. For the Northern Mixed Prairie in North Dakota it is estimated that mass of litter stabilizes in 11-16 years, depending on the plant community (Redmann 1975). At another location in North Dakota, litter recovered 4 years after burning Stipa-dominated communities while litter recovery took longer in Agropyron-dominated communities (Dix 1960).

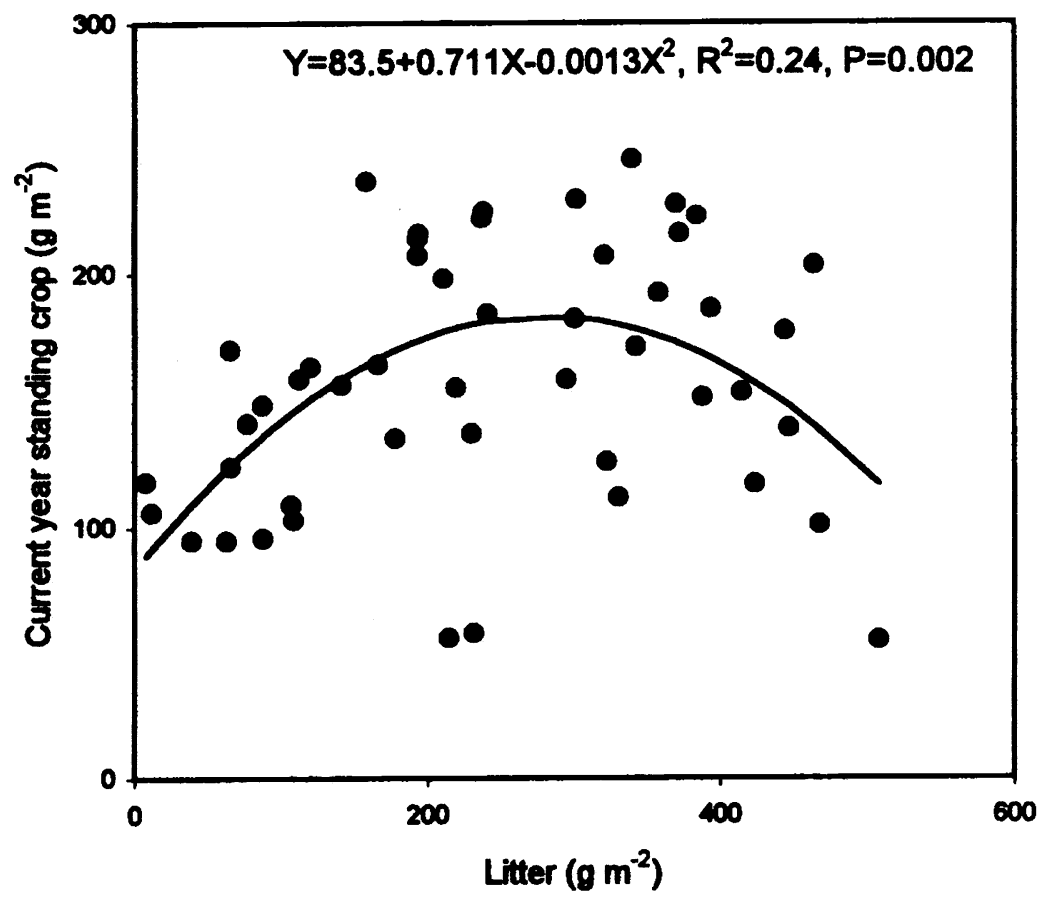

Fig. 2. The fitted regression line and observed values (solid circles) for current year standing crop and litter in burned Festuca-dominated plant communities.

\section{Total standing crop}

Over the 11-year period total standing crop in the control averaged $595 \mathrm{~g} \mathrm{~m}^{-2}$ (SE $\pm 14.5)$ in Festuca- and $398 \mathrm{~g} \mathrm{~m}^{-2}(\mathrm{SE} \pm$ 10.9) in Stipa-Agropyron-dominated communities. Total standing crop increased for about 7 to 8 years after burning before reaching a plateau in both communities (Fig. 4). The number of growing seasons since burning explained $67 \%$ and $58 \%$ of the variation in total standing crop in Festuca and Stipa-Agropyron communities, respectively. The unexplained variation in total standing crop is attributed to differences in production and decomposition among burn areas because total standing crop is categorized by growing seasons after burning. Redmann et al. (1993) reported total standing crop recovered to unburned levels 3 to 4 years after burning.

Return intervals of fires are an important consideration when including fire in the conservation of Festuca- and StipaAgropyron-dominated grasslands. Burning Festuca- and Stipa-Agropyron communities reduced or had no effect on current year standing crop. Although not definitive, our results also suggest that limited or excessive amounts of litter can hinder production in Festuca-dominated grasslands. Limiting litter accumulation by burning Festuca too frequently would limit production, as would burning infrequently and allowing large amounts (greater than about $350 \mathrm{~g} \mathrm{~m}^{-2}$ ) of litter to accumulate. In comparison our findings suggest precipitation places greater controls on production than amounts of litter in Stipa-Agropyron communities.

Aside from the changes in current year standing crop, litter and total standing crop after burning, it is imperative that other conservation goals be considered for Festuca- and Stipa-Agropyron-dominated grasslands. Annual burning in these grass- 

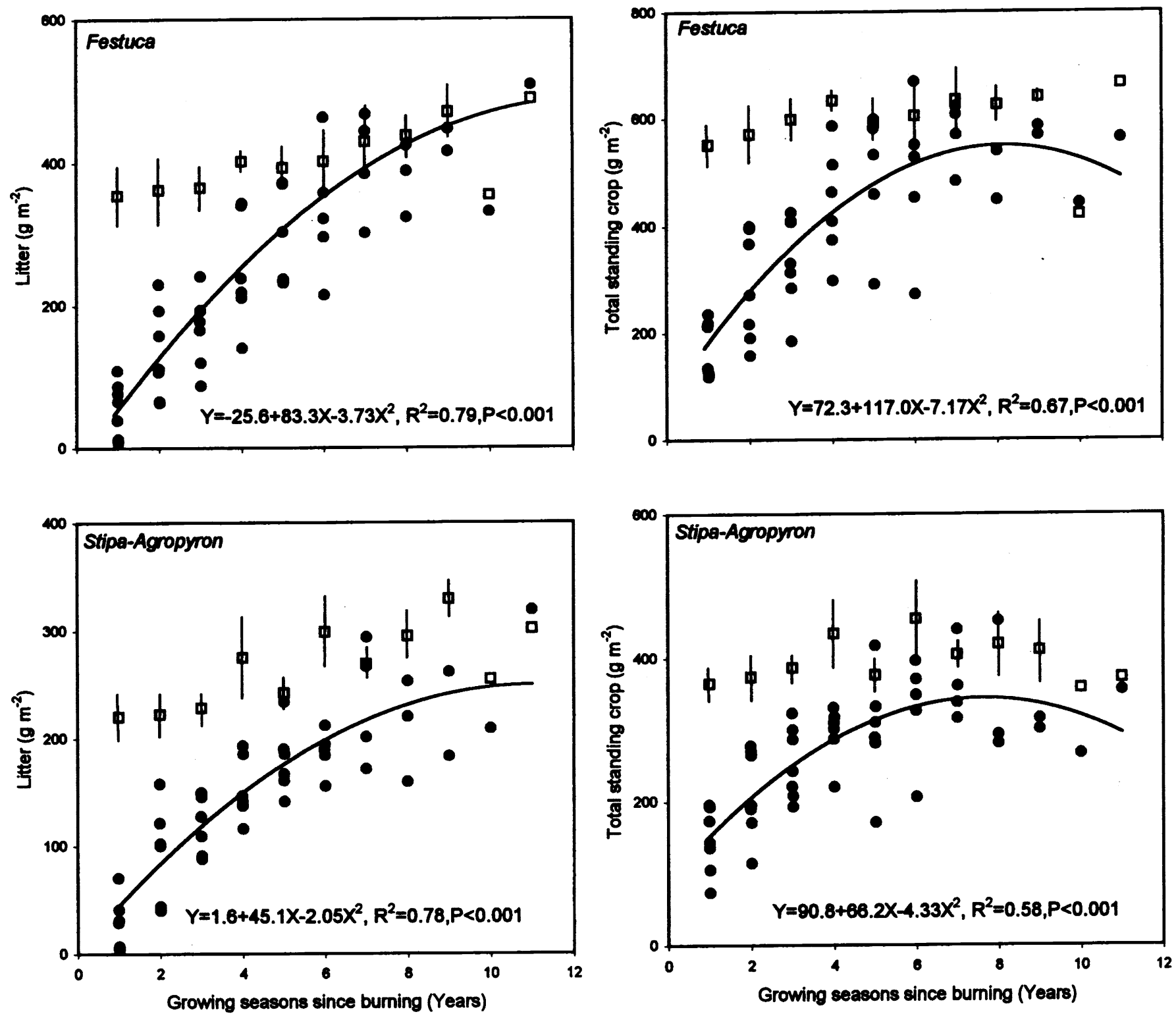

Fig. 3. Fitted regression lines and observed values for litter and growing seasons since burning in Festuca- and Stipa-Agropyron-dominated plant communities. Solid circles are observed litter after burning and open squares with vertical lines are means \pm SE for the control.

Fig. 4. Fitted regression lines and observed values for total standing crop versus growing seasons since burning in Festuca- and Stipa-Agropyron-dominated plant communities. Solid circles are total standing crop observed after burning and open squares with vertical lines are means $\pm S E$ for the control.

lands changes the structure in these grasslands by favoring species of warmer and drier conditions (Anderson and Bailey 1980). Furthermore Redmann (1991) argued that losses of nitrogen to volatilization by burning can exceed nitrogen inputs by 3- to 6-fold, and burning more frequently than every 4 years could cause a negative nitrogen balance in these grasslands.

Eighty-two percent of the native prairie in Saskatchewan has been cultivated for growing annual crops (Saskatchewan Agriculture and Food 1998), and about 5\% of the prairie dominated by plains rough fescue remains (Grilz and Romo 1995). Prairie remnants such as Kernen Prairie are important habitats for many species of wildlife, and are especially valuable as developed agricultural and urban lands often surround these remnant prairies. For example, certain species of birds require grasslands that have recovered from burning while others are most abundant when plant communities are in various states of recovery after burning (Pylypec 1991, Madden et al. 1999, 2000). Conservation goals of grasslands may also require significant amounts of dead plant material to provide nesting cover and foraging sites for wildlife. Burning should be infrequent (11 years or longer) when maintenance of large amounts of litter or total standing crop are concerns in both Festuca and Stipa-Agropyron communities. Five(Trottier 1985) to 10 (Wright and Bailey 1982) year return intervals have also been proposed for Fescue Prairie. Barrett (1997, 1999) estimated fire return intervals averaged about 10 to 26 years and ranged from 1 to 60 years in Fescue Prairie in the foothills of the Rocky Mountains in Montana. The actual frequencies of burn- 
ing needed to achieve conservation goals must be adjusted for management objectives and prevailing conditions of the prairie remnant under consideration. In practice, conservationists should probably strive to maintain a mosaic of burned patches within remnants of Festuca- and Stipa-Agropyron-dominated grasslands, each in various states of recovery.

\section{Literature Cited}

Anderson, H.G. and A. W. Bailey. 1980 Effects of annual burning on grassland in the Aspen Parkland of east-central Alberta. Can. J. Bot. 58:985-996.

Abrams, M.D., A.K. Knapp, and L.C. Hulbert. 1986. A ten-year record of aboveground biomass in a Kansas Tallgrass Prairie: Effects of fire and topographic position. Amer. J. Bot. 73:1509-1515.

Archibold, O.W., L.J. Nelson, E.A. Ripley, and L. Delanoy. 1998. Fire temperatures in plant communities of the Northern Mixed Prairie. Can. Field-Nat. 112:234-240.

Baines, G.B.K. 1973. Plant distributions on a Saskatchewan prairie. Vegetatio 28:99-123.

Barrett, S.W. 1997. Fire history of Glacier National Park: Hudson Bay drainage. U.S.D.I. National Park Service Contract CX 1430-5-0001. Final Report. West Glacier, Mont.

Barrett, S.W. 1999. Fire regimes on the Pine Butte Swamp Preserve, Montana. Final Report for The Nature Conservancy. Choteau, Mont.

Boerner, R.E.J. 1982. Fire and nutrient cycling in temperate ecosystems. Biosci. 32:87-192.

Bork, E.W., T. Thomas, and B. McDougall. 2001. Herbage response to precipitation in central Alberta boreal grasslands. J. Range Manage. 54:243-248.

Briggs, J.M. and A.K. Knapp. 1995. Interannual variability in primary production in Tallgrass Prairie: Climate, soil moisture, topographic position, and fire as determinants of aboveground biomass. Amer. J. Bot. 82:1024-1030.

Collins, S.L. and L.L. Wallace. 1990. Fire in North American Tallgrass Prairies. Univ. Oklahoma Press, Norman, Okla.

Coupland, R.T. 1950. Ecology of Mixed Prairie in Canada. Ecol. Monogr. 20:271-315.

Coupland, R.T. and T.C. Brayshaw. 1953. The Fescue Grassland in Saskatchewan. Ecol. 34:386-405.

Dix, R.L. 1960. The effects of burning on the mulch structure and species composition of grasslands in western North Dakota. Ecol. 41:49-56.

Engle, D.M. and P.M. Bultsma. 1984. Burning of Northern Mixed Prairie during drought. J. Range Manage. 37:398-401.

Environment Canada, Atmospheric Environment Service. 1993. Canadian climate normals 1961-1990; Vol. 2: Prairie Provinces. Environ. Canada, Ottawa, Ont.
Facelli, J.M. and S.T.A. Pickett. 1991. Plant litter: Its dynamics and effects on plant community structure. Bot. Rev. 57:1-32.

Gerling, H.S., A.W. Bailey, and W.D. Willms. 1995. The effects of burning on Festuca hallii in the parklands of central Alberta. Can. J. Bot. 73:937-942.

Grilz, P.L. and J.T. Romo. 1994. Water relations and growth of Bromus inermis Leyss (smooth brome) following spring or autumn burning in a Fescue Prairie. Amer. Midl. Nat. 132:340-348.

Grilz, P.L. and J.T. Romo. 1995. Management considerations for controlling smooth brome in Fescue Prairie. Nat. Areas J. 15:148-156.

Hopkins, H.H. 1954. Effects of mulch upon certain factors of the grassland environment. J. Range Manage. 7:255-258.

Johnston, A., J.F. Dormaar, and S. Smoliak. 1971. Long-term grazing effects on Fescue Grassland soils. J. Range Manage. 24:185-188.

Knapp, A.K. 1984. Post-burn differences in solar radiation, leaf temperature and water stress influencing production in a lowland Tallgrass Prairie. Amer. J. Bot. 71:220-227.

Knapp, A.K. and T.R. Seastedt. 1986. Detritus accumulation limits productivity of Tallgrass Prairie. Bioscience 36:662-668.

Kowalenko, B.L. and J.T. Romo. 1998. Regrowth and rest requirements of northern wheatgrass following defoliation. J. Range Manage. 51:73-78.

Madden, E.M., A.J. Hansen, and R.K. Murphy. 1999. Influence of prescribed fire history on habitat and abundance of passerine birds in Northern Mixed-Grass Prairie. Can. Field-Nat. 113:627-640.

Madden, E.M., R.K. Murphy, A.J. Hansen, and L. Murray. 2000. Models for guiding management of prairie bird habitat in northwestern North Dakota. Amer. Midl. Nat. 144:377-392.

Neter, J., W. Wasserman, and M.H. Kutner. 1990. Applied linear statistical models. Third edition. Richard D. Irwin, Inc., Boston, Mass.

Old, S.M. 1969. Microclimate, fire, and plant production in an Illinois prairie. Ecol. Monogr. 39:355-384.

Pylypec, B. 1986. The Kernen Prairie-a relict Fescue Grassland near Saskatoon, Saskatchewan. Blue Jay 44:222-231.

Pylypec, B. 1991. Impacts of fire on bird populations in a Fescue Prairie. Can. Field-Nat. 105:346-349.

Rauzi, F. 1960. Water-intake studies on range soils at three locations in the northern plains. J. Range Manage. 13:179-184.

Redmann, R.E. 1975. Production ecology of grassland plant communities in western North Dakota. Ecol. Monogr. 45:83-106.

Redmann, R.E. 1978. Plant and soil water potential following fire in a Northern Mixed Grassland. J. Range Manage. 31:443-445.

Redmann, R.E. 1991. Nitrogen losses to the atmosphere from grassland fires in Saskatchewan, Canada. Int. J. Wildland Fire 1:239-244.

Redmann, R.E. 1992. Primary productivity. p. 75-93. In: R.T. Coupland (ed.) Natural grasslands. Introduction and western hemisphere. Ecosystems of the world 8A. Elsevier, Amsterdam.
Redmann, R.E., J.T. Romo, B. Pylypec, and E.A. Driver. 1993. Impacts of burning on primary productivity of Festuca and StipaAgropyron grasslands in central Saskatchewan. Amer. Midl. Nat. 130:262-273.

Ripley, E.A. and O.W. Archibold. 1999. Effects of burning on prairie aspen grove microclimate. Agr., Ecosystems, Environ. 72:227- 237

Romo, J.T., P.L. Grilz, R.E. Redmann and E.A. Driver. 1993. Standing crop, biomass allocation patterns and soil-plant water relations in Symphoricarpos occidentalis Hook. following autumn or spring burning. Amer. Midl. Nat. 130:106-115.

Saskatchewan Agriculture and Food. 1998. Agricultural statistics 1998. Saskatchewan Agr. and Food, Statistics Branch, Regina, Sask.

Sims, P.L. and J.S. Singh. 1978. The structure and function of ten western North American grasslands. J. Ecol. 66:547-572.

Smoliak, S. 1986. The influence of climatic conditions on production of Stipa-Bouteloua prairie over a 50 -year period. J. Range Manage. 39:100-103.

Snedecor, G.W. and W.G. Cochran. 1980. Statistical Methods, Seventh edition. Iowa State University Press, Ames, Iowa.

Town, G. and C.E. Owensby. 1984. Longterm effects of annual burning at different rates on ungrazed Kansas Tallgrass Prairie. J. Range Manage. 37:392-297.

Trottier, G.C. 1985. Evaluation of the prescribed burn study, Prince Albert National Park. Parks Research Group, Canadian Wildlife Service. Edmonton, Alberta.

Vogl, R.J. 1974. Effects of fire on grasslands. p.139-174. In: T.T. Kozlowski and C.E. Ahlgren (eds.) Fire and ecosystems. Academic Press, New York, N.Y.

Walter, H. and H. Lieth. 1960-1967. Klimadiagramm-Weltatlas. G. Fischer, Jena (unnumbered ed).

Weaver, J.E. and N.W. Rowland. 1952. Effects of excessive natural mulch on development, yield, and structure of native grassland. Bot. Gaz. 114:1-19.

Whisenant, S.G. and D.W. Uresk. 1989. Burning upland mixed prairie in Badlands National Park. Prairie Nat. 21:221-227.

Willms, W.D. 1988. Response of rough fescue (Festuca scabrella) to light, water, temperature, and litter removal under controlled conditions. Can. J. Bot. 66:429-434.

Willms, W.D., S.M. McGinn, and J.F. Dormaar. 1993. Influence of litter on herbage production in the Mixed Prairie. J. Range Manage. 46:320-324.

Willms, W.D., S. Smoliak, and A.W. Bailey 1986. Herbage production following litter removal on Alberta native grasslands. J. Range Manage. 39:536-540.

Wright, H.A. and A.W. Bailey. 1982. Fire ecology, United States and Southern Canada. John Wiley and Sons, New York, N.Y.

Zhang, J. and J.T. Romo. 1994. Defoliation of a northern wheatgrass community: Aboveand below-ground phytomass productivity. $\mathrm{J}$. Range Manage. 47:270-284. 